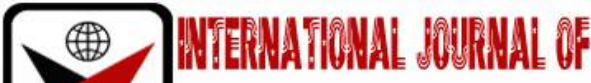

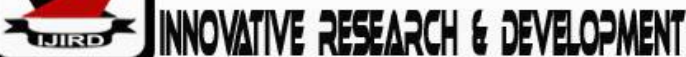

ISSN $2278-0211$ (Online)

\section{Analysis of Technical Efficiency of Catfish Production in EkitiState of Nigeria}

Ajiboye Abiodun
Senior Lecturer, Department of Agricultural Economics and Extension Services,
Ekiti State University, Nigeria
Adekunmi A.O.
Eenior Lecturer, Department of Agricultural Economics and Extension Services,
Ekiti State University, Nigeria
Osundare F.0.
Reader, Department of Agricultural Economics and Extension Services,
Ekiti State University, Nigeria
Oluwatusin F.M.
Reader, Department of Agricultural Economics and Extension Services,
Ekiti State University, Nigeria
Toluwase S.0.W.
Reader, Department of Agricultural Economics and Extension Services
Ekiti State University, Nigeria
Amao S.A.
Chief Lecturer, Department of Agricultural Technology,
Oyo State college of Agriculture and Technology, Nigeria

\begin{abstract}
:
The study investigated the technical efficiency of catfish production in Ekiti State of Nigeria and explored their determinants. Primary data were collected from 120 catfish farmers. Descriptive statistics was used to explain the socioeconomic and the enterprise characteristics of the respondents. The stochastic frontier approach was employed in analyzing the efficiency indices and their determinants. The results showed that Youths that were under 45 years account for majority of the respondents. The study accentuated the important need of women participation in catfish production. All of them attended schools at different levels which should be a boost to managerial abilities of the fish producers. Almostall the farmers (96\%) adopted the earthen pond method rather than the concrete pond system because of issues relating to cost. About 89\% of them had a stock capacity that ranged between 500 and 1000 fingerlings which stipulated that most of them were small scale operators. Only two of the efficiency correlates were significant. These are stock capacity and quantity oflabour. The return to scale was 0.136 which suggested that catfish farming was still a profitable venture. Fairly high inefficiencies were established in many of the farms and improvement of these was very possible if the fish farmers making up this number adopted the techniques of more efficient farms in the area.
\end{abstract}

Keywords: Technicalefficiency, catfish, stochasticfrontier, returns to scale

\section{Introduction}

The importance of fish in the diet of every person in the world cannot be over emphasized. Fish is not just a global food for humans alone both also a source of animal protein, in the diet of some animals. Aquaculture, popular known as domestic fish rearing is a geographically extensive and traditionally tenacious means of ensuring food security and poverty alleviation in many developing countries. In Nigeria, like any other parts of the world, fish farming occupies a very substantial space in the livestock subsector asit serves as a source of income and job creation for a good number of people, most especially in the rural areas where agriculture and agriculture-related activities are their major sources of livelihood. As much as fish is very essential in solving the animal protein deficiency in the diet of Nigerians, the imbalance between the supply and demand of this product has always downplayed this importance over the years. It is not an overstatement to say that demand far outweighs supply of fish in Nigeria and this is capable of exposing the teeming population to malnutrition (Oyakhilomen and Zibah, 2013). Since the Nigerian independence in 1960, there have been flurries of literature (Aromolaran 1999, Mbanasor 2002, Nworgu 2002, Oteku et al., 2006), indicating a dearth of animal protein in the diet of majority of Nigerian households. The per capita consumption level had persistently been below the standard daily FAOrequirement of 35 - 45g for an adult of $60 \mathrm{~kg}$ body weight which is less than 20 percent of this minimum daily 
requirement and helps to explain the country's widespread malnutrition .This daily animal protein consumption in Nigeria is less than 8 g per person, (Obioha, 1992). Hence the desired sustainable growth and Development is still very much far to come by .In order to meet demand and keep sustaining the animal protein markets in the country, fish importation in Nigeria is to the tune of over 900,000 metric tonnes (Ozigboet al., 2014) making Nigeria one of the largest importers of fish and fish products among the developing countries (Olagunjuet al., 2007). With the present frowns of successive governments at importation of food items in Nigeria, it is obvious that the supply-demand gap will keep widening if domestic growth of the livestock industry is not stimulated.

According to FAO (2005), report Nigeria, the most populous nation in Africa, has an aquaculture potential that is as high as $75 \%$ of $923,768 \mathrm{~km} 2$ of the land mass and 14 million hectares of inland freshwater, however not up to $1 \%$ is engaged in fish production. Though Nigeria is known to be very popular in farming as almost 70\% of the citizens are engaged therein but the fish farming subsector can be best described as being at the infant stage when compare to the large market potential for its production and marketing (Nwiro, 2012). Nigeria can substitute fish importation with domestic production to create jobs, reduce poverty in rural and peri-urban areas where 70 per cent of the population live and ease the balance of payments deficits (Areola, 2007).Nigerian annual fish demand is 2.7 million metric tonnes and just $30 \%$ of this demand is locally met culminating in an whooping spending ofN125 bn (US625m) of fish imports. In Nigeria the per capital fish consumption is $11 \mathrm{~kg}$ which is significantly lower than the global average and less than that of cote dvoire which $13.5 \mathrm{~kg}$ not to talk of the developed countries.Aquaculture in Nigeria encompass both the extensive and intensive system of farming and with different kinds of spices in stock. The domination of catfish among the most commonly cultured species of fish in Nigeria is very apparent even at the local fish markets (Issaet al., 2014).Catfish commands very good commercial value both in the local and international markets.

Due to its fast growth, high prolificacy and adaption to supplement feed, catfish rearing is essential to the sustainability of the aquaculture industry in the country, Osawe(2004). Some of the constraints leading to shortfalls in supply amongst others are inadequate finance, lack of skilled manpower, and high cost of inputs. Most studies have reported the cost of fish feed to be high and always a significant variable, and also the unavailability of good quality fingerlings (Oladejo, 2010; 2010; Omobepadeet al., 2015). This study endeavored to proffer solution to thesequestions: what is the socio economic and enterprise characteristics of fish farmers in Ekiti State? What are the technical efficiency levels of the farmers and what are the factors that influenced these efficiency levels?

\section{Material and Method}

\subsection{Study Area}

This study was carried out in Ekiti state, Nigeria. The state lies within the tropics between Longitudes $4^{\circ} 451$ and $6^{\circ} 451$ East of the Greenwich meridian and latitudes $7^{\circ} 151$ and $8^{\circ} 51$ North of the Equator. The state experiences a typical tropical climate with two different seasons, raining season from April-October while the dry season is between November and March. The state shares boundary in the North with Kwara and Kogi states in the East and South with Ondo state and in the west with Osun state. The state has a population of about 2,384,212 which represents about $1.7 \%$ of the nation's total population with a covered land area of $6,353 \mathrm{~km} 2$ (NBS, 2008; NPC, 2006). The average annual rainfall is between 2000 and $2400 \mathrm{~mm}$ while the average annual temperature rangesbetween 20 and $27^{\circ} \mathrm{C}$. There are sixteen Local Government Areas (LGAs) in the state.

\subsection{Sampling Technique and Data Analysis}

A multi-stage sampling procedure was used to select the respondents for this study. The first stage involved random selection of eightLGAs out of the sixteen LGAs in the state. The second stage involved random selection of one community from each of the selected LGAs. At the third stage, random selection of fifteen respondents from the selected communities was carried out. Thus, a total of 120 respondents were used for the study. A well-structured questionnaire and interview schedule were used to elicit information from the respondents. The data collected were analyzed with the use of descriptive statistics and Stochastic production efficiency frontier

\subsection{Stochastic Production Efficiency Frontier}

The analytical frame work guiding the paper can be represented in the manner of Battese et al; (1996) who proposed the use of stochastic frontier specifications that combined models for the technical inefficiency effects and simultaneously estimate all the parameters involved. In this case the $U_{i} S$ that account for technical inefficiency in production are assumed to be random variables which are independently distributed as truncations at zero of a normal distribution with mean $m$ and variance $S^{2}$ where $M_{1}=f\left(z_{i}, d\right)$ and $z_{i}$ is a vector containing farm specific factors and a constant, $d$ is a vector of parameters to be estimated and $f(x)$ is a suitable functional form, usually assumed to be linear. (Ajibefun and Daramola, 1999)

A production function can be specified for cross-sectional data with an error term containing two components, one that account for technical inefficiency $\left(\mathrm{v}_{\mathrm{i}}\right)$ and a second one that accounts for random effects ( $\left.\mathrm{v}_{\mathrm{i}}\right)$ the frontier production function proposed by Aigneretal; (1977) is as follows

$y_{i}=f(x, \beta)+E \quad i=1,2 \ldots \ldots . N$

Where $y_{i}$ is the output quantity of the $i^{\text {th }}$ farm; $x_{i}$ is a $(K \times 1)$ vector of quantities of input employed by the $i^{\text {th }}$ farm in the production of $\mathrm{y}$; and $\mathrm{B}$ is a vector of unknown production function parameters to be estimated $\mathrm{e}_{\mathrm{i}}$ is an error term made up of two components. 


$$
E_{i}=v_{i}-u_{i}
$$

The $v_{\mathrm{i}}$ `s are assumed to be independently and identically distributed random errors having a normal distribution with mean zero and variance $\sigma_{v}^{2}$ thus, the $\mathrm{v}_{\mathrm{i}}$ accounts for measurement errors and other factors that are beyond the farmers control. The $\mathrm{v}_{\mathrm{i}} \mathrm{S}$ is assumed to be independent of the $\mathrm{u}_{\mathrm{i}} \mathrm{S}$ which are non-negative random errors $\left(\mathrm{u}_{\mathrm{i}}>0, \nabla_{i}\right)$. The $\mathrm{u}_{\mathrm{i}} \mathrm{S}$ are assumed to account for technical inefficiency in protection and assumed to be independent and identical distributed exponential or half- normal variables.

If we combine equation 1 and 2, assuming a Cobb-Douglas specification, the stochastic frontier production for this study could be rewritten as follows.

$\ln y_{i}=\beta_{o}+\sum_{i=1}^{m} \beta_{j} \ln x_{i j}+v_{i}-u_{i} \quad i=1,2, \ldots \ldots . . N$

Where $\mathrm{y}_{\mathrm{i}}$ is the output of farm $\mathrm{i}, \mathrm{X}_{\mathrm{ij}}$ is the amount of input $\mathrm{j}$ used by farm $\mathrm{i}, \beta_{j}$ are parameters to be estimated. The output values are bounded above by the stochastic variable, $\exp \left(x_{i} \beta+v_{i}\right)$. The random error, $\mathrm{V}_{\mathrm{i}}$, can be positive or negative. Therefore stochastic frontier technical efficiency can be written as

$$
T E_{i}=\frac{y_{i}}{\exp \left(x_{i} \beta\right)}=\frac{\exp \left(x_{i} \beta-u_{i}\right)}{\exp \left(x_{i} \beta\right)}=-\exp \left(u_{i}\right)(4)
$$

Where $\mathrm{y}_{\mathrm{i}}$ is the observed output and $\exp \left(x_{i} \beta\right)$ is the estimated value of frontier output. This is called an output-oriented Farell measure of technical efficiency. Technically efficient farms are those that operate on the production frontier and the level by which a farm lies below the production frontier is regarded as the measure of technical efficiency.

\subsubsection{TheModel}

The model proposed for the analysis of egg production, involving stochastic production function is presented as follows.

$\ln \left(Y_{i}\right)=\beta_{o}+\beta_{1} \ln x_{1}+\beta_{2} \ln x_{2}+\beta_{3} \ln x_{3}+\beta_{4} \ln x_{4}+v_{1}-u_{i}$

Where ln denotes natural logarithm (logarithm to base e) the subscript i refers to the $1^{\text {th }}$ farmer in the sample; $i=1,2 \ldots . . . N$, where $\mathrm{N}$ is the number of poultry farms. $\mathrm{Y}_{\mathrm{i}}$ represents a weighted output of fish produced in kilograms per period; $\mathrm{X}_{1}$ stocking capacity per period; $X_{2}$ represent represents the total quantity of feed (in kilograms) per period, $X_{3}$ represents the pond size; $\mathrm{X}_{4}$ represent the total number of labour in man-days.The $\beta_{s}$ are the unknown parameters for the production function of the $\mathrm{i}^{\text {th }}$ farm. The $\mathrm{V}_{\mathrm{i}} \mathrm{s}$ are random errors associated with measurement errors in broiler production, or combined effects of input variables not included in the production function. The $\mathrm{V}_{\mathrm{i}} \mathrm{s}$ are assumed to be identically and independently distributed $N\left(0, \sigma_{v}^{2}\right)$ random variables. The $\mu_{\mathrm{i}} \mathrm{s}$ are non- negative random variable, associated with technical inefficiency of production, assumed to be identically and independently distributed, such that the technical inefficiency effect for the $i^{\text {th }}$ farms, $\mu_{\mathrm{i}}$, is obtained by truncation (at zero) of the normal distribution with mean, $\mu_{\mathrm{i}}$, and variance $\sigma^{2}$, (Battese and Hassan, 1998). Such that

$$
\mu_{i}=\delta_{0}+d_{1} \delta_{1}+\delta d_{2} \delta_{2}+d_{3} \delta_{3}+d_{4} \delta_{4}+d_{5} \delta_{5}
$$

Where $\delta_{1}$ is the age of eth farmer in years; $\delta_{2}$ denotes the gender which is dummy; $\delta_{3}$ represent educational level; $\delta 4$ household size and $\delta_{5}$ denotes the experience of farmers in years $\sigma_{\mathrm{s}}$ and $\sigma^{2} \mathrm{~s}$ are unknown parameters to be estimated. The parameters of the stochastic frontier production function was be estimated using the programme frontier 4.1

\section{Results and Discussion}

Above is the display of the distribution of the socio economic characteristics of the respondents.According to the table it is revealed that only $1.7 \%$ of the respondents were female. All the remaining $98.3 \%$ were male. The fewness of female farmers in fish production is very difficult to explain because artisanal fishing is not an enterprise that could naturally be restricted to the male gender alone. One, because it is not as labour-demanding as other agricultural enterprises and two it could even be carried out in homes such as the backyards. However it could be that female decided to stay put with processing and marketing which is a typical thing for them to do. Distribution according to age showed that youth that were under 45 years account for majority of the respondents. Older men that were above 50 years were also adequately involved in the enterprise. Some of them were married while some were divorced .Each of this group account for about half of the respondents respectively. (48.3\% and 50\%).Only $2 \%$ of them were widowed .Distribution according to educational status showed that all of them attended schools at different levels. Those that had primary education were $29 \%$ of the respondents, $16 \%$ had secondary education while $18 \%$ had tertiary education. A large percentage of about $48 \%$ had only adult education. This showed that the illiterate folks in the area did not key into the 
opportunities that could be derived in engaging in enterprises such as artisanal fisheries. This is probably due to dearth of information or due to the associating risk and even space to embark on the operation. Distribution according to year of experience showed that none of them was a new entrant.Year of experience was as many as 30 years and above for majority of them. This is expected to be an added advantage in terms of their efficiency. The table revealed that about $53 \%$ of them were part time farmers meaning that they have other jobs they engaged in either as primary or secondary occupations. Distribution according to family size showed that small families were not very much represented because only $4 \%$ fell within the family members of $1-3$ while $75 \%$ were between $4-6$ members. $20.8 \%$ had $7-8$ members. This indicates that family labour would not be difficult to come by for those families that have physically able men and women. The distribution according to income showed that almost all of them did not attain to an income level of 1 million naira per annum.only 2 of the respondents had income that rose above $\$ 800000$.Hence comparing with the present economic condition, the respondents had not been able to successfully tackle the menace of poverty through artisanal fisheries except those that had other reliable means of income, that is for those in the part time. The chosen enterprise revealed that only $3.5 \%$ of them operated fingerling. While the remaining $6.7 \%$ produced adult fish. This means that those in the former group were intermediate producers and served as stocking sources for the remaining. Twotypes of technology were available namely concrete and earthen pond systems. $96.7 \%$ operated earthen ponds while the remaining $3.7 \%$ operated concrete pond systems. Such low numbers operated concrete ponds most likely because of its capital-intensiveness and that they hadnoaccess to river banks for earthen ponds to be constructed. The table revealed that all of the producers operated small-scale farms as depicted by the number of fish reared. Only $3.3 \%$ if them produced above 1000 fishes.

\begin{tabular}{|c|c|c|}
\hline Variables & Frequency & Percentages \\
\hline Age & & \\
\hline$<35$ & 11 & 9.1 \\
\hline $36-40$ & 29 & 24.2 \\
\hline $41-45$ & 31 & 25.9 \\
\hline $46-50$ & 22 & 18.3 \\
\hline$>50$ & 27 & 22.5 \\
\hline Mean & 46.7 & \\
\hline Sex & & \\
\hline Male & 118 & 98.3 \\
\hline Female & 02 & 1.7 \\
\hline Marital status & & \\
\hline Married & 58 & 48.3 \\
\hline Single & 60 & 50.0 \\
\hline Divorced & 02 & 1.70 \\
\hline Household size & & \\
\hline $1-3$ & 05 & 4.2 \\
\hline $4-6$ & 90 & 75.0 \\
\hline Above 6 & 25 & 20.8 \\
\hline Educational status & & \\
\hline Adult education & 48 & 40 \\
\hline Primary & 35 & 29.2 \\
\hline Secondary & 19 & 15.8 \\
\hline Tertiary & 18 & 15 \\
\hline Occupational status & & \\
\hline Full-time & 64 & 53.8 \\
\hline Part-time & 56 & 46.7 \\
\hline Experience & & \\
\hline Less than 30 & 39 & 32.5 \\
\hline $21-30$ & 61 & 50.8 \\
\hline More than 30 & 20 & 16.7 \\
\hline
\end{tabular}

Table 1: Socio-Economic Distribution of the Respondents 


\begin{tabular}{|c|c|c|}
\hline Variables & Frequency & Percentages \\
\hline Enterprise type & 116 & 96.7 \\
Grow out operation & 04 & 3.5 \\
Fingerling operation & & \\
Technology type & 116 & 96.7 \\
Earthen pond & 04 & 3.5 \\
Concrete pond & 09 & 7.5 \\
Stocking capacity & 107 & 89.2 \\
Above 500 & 4 & 3.3 \\
501-1000 & & \\
Above 100 & & \\
\end{tabular}

Table 2: Distribution According to Enterprise Characteristics

The result of the Maximum livelihood estimate of stochastic frontier production function of fish farmers in ekiti state is presented in table 3 below. The table revealed the estimate of the parameters for this function and the variance parameters of the model. The variance parameter sigma was $4.31 \times 10^{8}$ and was significant at $1 \%$ level of probability. The value of gamma was estimated to be $3.10 \times 10^{-6}$ and was highly significant at $1 \%$ level of probability. The coefficient of the stock of fish was 583 and it was significant at $1 \%$ level, meaning that farms could still increase their fish production substantially by increasing their stock. Quantity of feed intakelabour was significant at $5 \%$ and had a coefficient of -0.48 . This means that the morelabour the less the Technical Efficiency of the farms. This suggests that many of the labour are just disguisedly employed in the catfish business. This is typical of the household who rely on family size as the source of labour to the Farms. Farmers should therefore know the limits for which labour should be utilized so as to avoid idleness; otherwise the excess would always amount to a waste of resources especially if they were directly paid in cash from the proceeds of the pond operation. The inefficiency parameters considered in this study include the poultry farmer's age, gender, educational level and household size, experience andincome. According to the result, educational level of the respondents is the only significant variable and this is at $5 \%$ with a coefficient of -3869 . This stipulates that an increase in the educational level of the respondents leads to a decrease in the inefficiency and vice versa. This result is agreeing with expectation because it supported the connection between educational endowment and technical know-how. Education means knowledge and it is expected to reflect in the manner that enterprises such as catfish business is manned.

\begin{tabular}{|c|c|c|}
\hline Variables & Coefficients & P values \\
\hline \multicolumn{3}{|c|}{ Efficiency parameters } \\
\hline Stocking Capacity & $583.07^{* * *}$ & 0.00 \\
\hline Feed cost & 12.91 & 0.21 \\
\hline Pond size & -9.76 & 0.39 \\
\hline Labour & $-0.478^{* *}$ & 0.01 \\
\hline Age & 669.75 & 0.17 \\
\hline Gender & 20215 & 0.18 \\
\hline Education & $-3869^{* *}$ & 0.05 \\
\hline Household size & -847 & 0.62 \\
\hline Experience & 75.85 & 0.87 \\
\hline Sigma squared $\delta^{2}$ & $4.31 \times 10^{8}$ & \\
\hline Gamma $\Gamma$ & $3.10 \times 10^{-6}$ & \\
\hline \multicolumn{2}{|c|}{ Table 3: Result of the Stochastic Frontier Analysis } \\
${ }^{* * *}$ and $d^{* *}$ represent significance at 1\% and 5\% respectively
\end{tabular}

\begin{tabular}{|c|c|c|}
\hline Technical Efficiency Estimates & Frequency & Percentage \\
\hline$<0.30$ & 24 & 20.00 \\
\hline $0.30-0.59$ & 64 & 53.30 \\
\hline $0.60-0.89$ & 20 & 16.70 \\
\hline$\geq 0.90$ & 12 & 10.00 \\
\hline Min $=0.25$ & & \\
Max $=0.93$ & & \\
\hline Mean $=0.61$ & & \\
\hline
\end{tabular}

Table 4: Distribution of the Technical Efficiency Indices

The results of the TE estimates demonstrated that substantial inefficiency existed among the fish farms. Some of the farmers demonstrated poor efficiency while quite a few of them demonstrated a high efficiency of 0.9 and above as 
indicated by the by the percentage of 10.The mean efficiency, however suggested a gross average inefficiencies among the decision making units.

\begin{tabular}{|c|c|}
\hline Variables & Elasticities \\
\hline Skock size & 0.583 \\
\hline Costs of feed & 0.129 \\
\hline Pond size & -0.098 \\
\hline Labour & -0.478 \\
\hline RTS & 0.136 \\
\hline
\end{tabular}

Table 5: Elasticities of Production and Return to Scale

Table 5 displays the Elasticities of production and return to scale of fish farm operation in the area. The RTS is calculated as the sum total of all the estimated elasticities of production. The elasticity of quantity of labour and pond size was negative decreasing functions to the factor, indicating gross over-utilization of the input which characterizes stage 3 of the production process. The return to scale was 0.136 which is a very weak figure in that its deviation from unity is very large. Being a positive index, though, it signifies a positive decreasing return to scale and that catfish production in the study area is still in stage 2 of production.

\section{Conclusion}

The study investigated the technical efficiency of fish production in Ekiti state of Nigeria using a stochastic frontier approach. The results showed that fairly high inefficiencies were established in many of the farms and improvement of these is very possible if the fish farmers making up this number were more proactive. Highly inefficient farms could take the advantage of comparative advantagesacross the farms and improved performance could then be experienced if they adopted the techniques of more efficient farms.

\section{References}

i. Areola, F. O. (2007) Fish marketing and export potentials of fish and fisheries products of Nigeria. A lecture delivered at educative and informative aqua-culture workshop and aqua-exhibitions tagged: sustainable fisheries livelihood, management and food security in Nigeria. 23pp.

ii. Aromolaran, A.B. (1999): Analysis of consumption expenditure and consumer preference for selected animal products: the case of low income household in Warri, Nigeria. Nigerian journal of animal production (26): 129136.

iii. Aigner, D., Lovell, C. A. K., and Schmidt, P. (1977). Formulation and estimation of stochastic frontier production function model. Journal of Econometrics, 6: 21-37.

iv. Battese, G. E., and G. S. Corra. (1977). 'Estimation of a production frontier model: with application to the pastoral zone of Eastern Australia'. Australian Journal of Agricultural Economics, 21: 169-I79.

v. Issa, F. O., Abdulazeez, M. O., Kezi, D. M., Dare, J. S., and Umar, R. (2014). Profitability analysis of small-scale catfish farming in Kaduna State, Nigeria. Journal of Agricultural Extension and Rural Development, 6(8): 267-273.

vi. Mbanasor, J. A. (2002). 'Resource use pattern among poultry enterprises in Abia state, Nigeria'. Journal of Animal production. 29(1): $64-70$.

vii. NBS, 2008.Annual Abstract of Statistics. National Bureau of Statistics, Abuja.

viii. NPC., 2006. National Census Data for Nigeria. National Population Commission, Abuja, Nigeria,

ix. Nwiro, E. (2012) Fish Farming a Lucrative Business. Accessed online 20th October 2012 from http://www.thisdaylive.com/articles/fish-farming-a-lucrative-business/119253

x. Nworgu, F. C. (2007). 'Economic importance and growth rate of broiler chickens severed with fluted pumpkin (Teifariaoccidentials) leaves extract' African Journal of Biotechnology.16 (2).

xi. Obioha F. C. (1992) A guide to Poultry Production in the Tropics.Acena Publication Enugu, Nigeria. Pp139-140

xii. Oladejo A.J. (2010): Economic Analysis of Small-Scale Catfish Farming in Ido Local Government Area of Oyo State, Nigeria. Agricultural Journal 5(6): 318-321

xiii. Olagunju, F. I., Adesiyan, I. O., and Ezekiel, A. A. (2007).Economic viability of catfish production in Oyo State, Nigeria.Journal of Human Ecology, 21(2): 121 - 124.

xiv. Omobepade1, B. P., Adebayo, O. T., Amos, T. T. and Adedokun, B. C. (2015): Profitability Analysis of Aquaculture in Ekiti State, Nigeria. Nigerian Journal of Agriculture, Food and Environment. 11(1):114-119

xv. Oteku, I. T. J. O. Ige and I. M. Yessuf (2006).'An assessment of the factors influencing theconsumption of Duck meat in Southern Nigeria'. Pakistan Journal of Nutrition 5(5): $\quad 474-\quad 477$.

xvi. Oyakhilomen, O., and Zibah, R.G. (2013). Fishery production and economic growth in Nigeria: Pathway for sustainable economic development. Journal of Sustainable Development in Africa, 15(2): 99-109.

xvii. Ozigbo, E., Anyadike, C., Adegbite, O., and Kolawole, P. (2014). Review of aquaculture production andmanagement in Nigeria. American Journal of Experimental Agriculture, 4(10): 1137-1151. 